\title{
Література:
}

1. Руднева Л.Л. Исследование процессов утилизации растительных восков. Материаль VI Международного научно-технического Симпозиума "Современные энерго- и ресурсосберегающие технологии СЭТТ-2017», Международного научно-технического Форума «Первые международные Косыгинские чтения. Т. 2. Москва. ФГБОУ ВО «РГУ им. А.Н. Косыгина». 2017. С. 178-181.

2. ДСТУ 4774:2007 «Вироби косметичні для макіяжу на жировосковій основі. Загальні технічні умови». 2007. 4 с.

DOI https://doi.org/10.30525/978-9934-26-046-9-39

\section{ІННОВАЦІЙНІ МЕТОДИ ЗБАГАЧЕННЯ БЕРЕЗОВОГО СОКУ}

\section{Суткович Т. Ю.}

кандидат технічних наук, доцент,

доцент кафедри технологій харчових виробництв

і ресторанного господарства

ВНЗ Укоопспілки «Полтавський університет економіки і торгівлі м. Полтава, Украӥна

\section{Палвашова Г. I.}

кандидат технічних наук, дочент кафедри біоінженерії $і$ води Одеська начіональна академія харчових технологій м. Одеса, Украӥна

\section{Положишникова Л. О.}

кандидат технічних наук, доцент кафедри технологій харчових виробниџтв

і ресторанного господарства

ВНЗ Укоопспілки «Полтавський університет економіки і торгівлі» м. Полтава, Украӥна

Несприятливі фактори зовнішнього середовища впливають на організм людини. Зміцнення здоров'я населення може відбуватися шляхом включення в раціон продуктів харчування, що має виражений профілактичний і лікувальний вплив [1, с. 7]. 
Повноцінне і збалансоване харчування, з врахуванням його лікувально-оздоровчих функцій, вимагає поповнення раціону кожної людини близько 600 нутрієнтами. Одним із основних джерел цих речовин $\epsilon$ дикоростуча плодово-ягідна сировина, як культивована так і та, що плодоносить на лоні природи. Вона природно містить значну кількість біологічно активних речовин (БАР), які виявляють позитивний вплив на організм людини, діяльність його нервової і серцево-судинної систем та сприяють нормалізації функцій окремих органів [2, с. 9]. Тому швидке забезпечення організму людини БАР є одним із вагомих завдань сьогодення, вирішити яке можливо, розробляючи новий асортимент напоїв функціонального призначення.

Найвживанішим харчовим продуктом, який максимально швидко збагачує організм людини БАР і вирішує проблему мікронутрієнтного дефіциту $\epsilon$ натуральні соки та функціональні напої на їх основі [1, c. 69].

Завданням, яке потребує креативного вирішення, є необхідність в розробці напоїв, які б забезпечували максимальний відсоток відповідності добовим потребам людського організму в основних поживних та біологічно активних речовинах. Вирішення цього завдання можливе за рахунок впровадження таких технологічних прийомів, які б дали змогу отримувати сік з вищим ступенем збереження БАР.

Паралельно з вищезазначеними завданнями необхідно вирішувати проблему безвідходного використання сировини. Це можливо за рахунок впровадження технологій по комплексному використанню вторинної сировини. Саме вона в значних кількостях залишається поза увагою після основного процесу вилучення соку, хоча містить майже весь спектр необхідних нутрієнтів. Вирішення окреслених завдань $\epsilon$ досить актуальним і перспективним, які ми постараємось розв'язати, виконуючи дослідження в межах цієї наукової статті.

На сьогоднішній день існує багато соків, які за своєю природою не дуже багаті необхідними для людського організму нутрієнтами. Одним із таких є березовий сік [3, с. 29-30]. Тому доцільним є його насичення корисними компонентами дикорослих ягід.

Метою роботи є удосконалення технології отримання напоїв на основі березового соку шляхом використання вторинної дикорослої сировини із обліпихи та пришвидшення процесу екстракції БАР за рахунок використання ультразвукової обробки.

Для досягнення поставленої мети необхідно було вирішити низку взаємопов'язаних завдань: 
теоретично обгрунтувати доцільність використання нетрадиційної рослинної сировини для збагачення березового соку з метою підвищення його харчової цінності;

- дослідити вплив УЗ-обробки на фізико-хімічні показники отриманих напоїв.

Одним із яскравих представників дикорослих ягід є обліпиха. Окрім цукрів, вона містить вітаміни $\mathrm{B}_{1}, \mathrm{~B}_{2}$, PP, A, E, K, D, C, дубильні речовини, органічні кислоти, жирні олії, ефірні олії, пектинові речовини, мінеральні солі кальцію, магнію та заліза [4, с.17]. На скільки багаті вичавки обліпихи наведено в таблиці 1.

Таблиця 1

Фізико-хімічні показники вичавок із обліпихи $(n=3 ; p \geq 0,95)$

\begin{tabular}{|c|c|c|}
\hline $\begin{array}{l}\text { № } \\
\text { ㅍ/III }\end{array}$ & Показники & Значення \\
\hline 1. & Вміст сухих речовин, \% & 10,0 \\
\hline 2. & Вміст титрованих кислот,\% & 0,73 \\
\hline 3. & $\begin{array}{l}\text { Вміст L-аскорбінової кислоти, } \\
\text { мг/100г }\end{array}$ & 59,0 \\
\hline 4. & Вміст $\beta$-каротину, мг/100 г & 30,0 \\
\hline
\end{tabular}

Аналізуючи отримані дані, можна стверджувати, що вторинна сировина обліпи досить багата біологічно активними речовина. Тому iï доцільно використовувати для збагачення березового соку.

Користь березового соку очевидна, але варто розуміти: цей сік - не ліки, а дарований природою хороший напій з антиалергенними, протизапальними та імунозмічнюючими властивостями.

Таблиця 2

Фізико-хімічні показники березового соку $(\mathrm{n}=3 ; \mathrm{p} \geq \mathbf{0 , 9 5 )}$

\begin{tabular}{|c|c|c|}
\hline № п\п & Показники & Сік березовий \\
\hline 1. & Вміст сухих речовин, $\%$ & 5,00 \\
\hline 2. & Вміст титрованих кислот, $\%$ & 0,10 \\
\hline 3. & В’язкість, м $^{2} / \mathrm{c}^{-6} 10^{-6}$ & 6,43 \\
\hline 4. & Кольоровість, од.опт.густ & 0,05 \\
\hline
\end{tabular}

Збагачення березового соку, який містить незначну кількість БАР екстрактами вторинної сировини із обліпихи, забезпечить покращення харчової цінності. Безвідходне використання природніх ресурсів дасть 
змогу виготовляти функціональні напої, які мають антиоксидантну, загальнозміцнювальну, заспокійливу дію на організм людини

Одним із інноваційних методів попередньої обробки сировини $\epsilon$ застосування ультразвукової обробки. В результаті ультразвукової дії відбувається руйнування клітинних структур, що прискорює процес переходу корисних компонентів в екстрагент за рахунок дифузії [5, с. 167]. Екстрагентом слугував березовий сік. Вичавки в кількості $1: 2$ обробляли ультразвуком протягом певного часу. Після проведення процесу екстрагування отримані екстракти фільтрували і перевіряли на вміст сухих речовин, титрованих кислот, аскорбінової кислоти, $\beta$-каротину, в'язкість та кольоровість.

Таблиця 3

Вплив тривалості УЗ-обробки на зміни фізико-хімічних показників отриманого напою $(n=3 ; p \geq 0,95)$

\begin{tabular}{|c|c|c|c|c|c|c|c|c|}
\hline \multirow{2}{*}{ 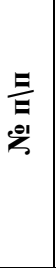 } & \multirow{2}{*}{ Показники } & \multirow{2}{*}{ 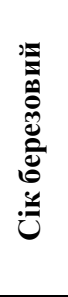 } & \multirow{2}{*}{ 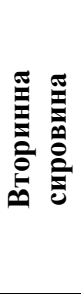 } & \multicolumn{5}{|c|}{ Тривалість обробки, хв } \\
\hline & & & & 10 & 15 & 20 & 25 & 30 \\
\hline \multicolumn{9}{|c|}{ Обліпиха } \\
\hline 1. & $\begin{array}{l}\text { Вміст сухих } \\
\text { речовин, } \%\end{array}$ & 5,0 & 10,0 & 5,8 & 6,2 & 6,8 & 7,0 & 7,1 \\
\hline 2. & $\begin{array}{l}\text { Вміст титрованих } \\
\text { кислот, } \%\end{array}$ & 0,1 & 0,73 & 0,44 & 0,48 & 0,52 & 0,58 & 0,50 \\
\hline 3. & $\begin{array}{c}\text { Вміст L- } \\
\text { аскорбінової } \\
\text { кислоти, мг/100г }\end{array}$ & - & 59,0 & 20,5 & 22,3 & 24,8 & 25,6 & 27,2 \\
\hline 4. & $\begin{array}{c}\text { Вміст } \beta \text {-каротину, } \\
\text { мг/100 г }\end{array}$ & - & 30,0 & 18,3 & 18,7 & 19,1 & 19,6 & 20,1 \\
\hline 5. & $\begin{array}{l}\text { В'язкість, } \\
\mathrm{M}^{2} / \mathrm{c} \cdot 10^{-6}\end{array}$ & 6,43 & - & 6,46 & 6,48 & 6,49 & 6,50 & 6,52 \\
\hline 6. & $\begin{array}{l}\text { Кольоровість, } \\
\text { од. опт. густ }\end{array}$ & 0,05 & - & 0,2 & 0,25 & 0,30 & 0,36 & 0,47 \\
\hline
\end{tabular}

Аналіз даних приводить до висновку, що за допомогою запропонованого методу ультразвукової обробки вторинної сировини дикоро164 
слих ягід обліпихи отримуємо напій, який в значній мірі збагачений біологічно активними речовинами.

Висновки. Підводячи підсумки отриманих даних, можна стверджувати, що обробка ультразвуком протягом лише 30 хв в порівнянні з традиційними способами екстракції, які тривають 6 ...2 24 год і більше, значно пришвидшує процес екстракції.

Отриманий напій містить в 1,4 рази більше сухих речовин, в 5 разів - титрованих кислот, в 9,4 разів зросла кольоровість; в'язкість зросла на 0,9 \% в порівнянні з контрольним зразком, яким слугував березовий сік. А 100 г отриманого напою забезпечує третину добової потреби у вітаміні С. Тому застосування обраного методу попередньої обробки вторинної сировини є доцільним, актуальним та такими, які виправдали наші очікування.

\section{Література:}

1. Капрельянц Л. В., Іоргачова К.Г. Функціональні продукти: монографія. Одеса : Друк, 2003. 312 с.

2. Хомич Г. П., Ткач Н. І. Використання дикорослої сировини для забезпечення харчових продуктів БАР: монографія. Полтава: РВВ ПУСКУ, 2009. 159 с.

3. Ільченко, Н. Що ви повинні знати про березовий сік. Безпека життєдіяльності. 2020. № 3. С. 29-30.

4. Гриник I. В., Москалець Т. 3., Москалець В. В., Шевчук Р. С. Обліпиха крушиновидна (Hippophae rhamnoides L.). - споживчоцінний та перспективний сировинний ресурс здорового харчування людини. Садівництво. 2018. Вип. 73. С. 17-24.

5. Хмелев В. Н., Сливин А. Н., Барсуков Р. В. Применение ультразвука высокой интенсивности в пищевой промышленности. Бийск : Изд-во Алт. гос.техн. ун-та, 2010. 203 с. 